\title{
Different substrates and environments in the production of passion fruit seedlings
}

\section{Diferentes substratos e ambientes na produção de mudas de maracujazeiro}

\section{Benedito Rios de OLIVEIRA ${ }^{1}$; Gilvanda Leão dos ANJOS ${ }^{2}$; Francielle Medeiros COSTA $^{3}$; Geise Bruna da Mata CAMILO ${ }^{4}$; Anacleto Ranulfo SANTO 5}

${ }^{1}$ Doutorando em Ciências Agrárias, Universidade Federal do Recôncavo da Bahia, Cruz das Almas - BA, E-mail:
benedito.ta@hotmail.com
${ }^{2}$ Mestre em Solos Qualidade e Ecossistema na Universidade Federal do Recôncavo da Bahia Cruz das Almas-BA, E-mail:
gilvandas218s2@gmail.com
${ }^{3}$ Mestre em Solos Qualidade e Ecossistemas, Universidade Federal do Recôncavo da Bahia, Cruz das Almas - BA, E-mail:
fran-eng@hotmail.com
${ }^{4}$ Mestre em Solos Qualidade e Ecossistema na Universidade Federal do Recôncavo da Bahia Cruz das Almas - BA, E-mail:
geise.camilo@sonointernational.com
${ }_{5}^{5}$ Professor titular pela Universidade Federal do Recôncavo da Bahia Cruz das Almas, E-mail: anacleto@ufrb.edu.br

Recebido em: 08-05-2019; Aceito em: 05-02-2020

\begin{abstract}
The substrate has great importance in seedling production. Its choice must be carefully considered, since it can provide the best conditions for seed germination and seedling development. This study evaluates which light and substrate favor the production of good quality passion fruit seedlings. The experiment was conducted in the experimental field of the Federal University of Recôncavo da Bahia, in Cruz das Almas city, Bahia State, Brazil. The design was completely randomized, in a $4 \times 5$ factorial scheme, with four substrates: 1) Soil; 2) Soil + NPK (N: $100 \mathrm{~kg} \mathrm{ha}^{-1}$; P: $100 \mathrm{~kg} \mathrm{ha}^{-1}$; and K: $50 \mathrm{~kg} \mathrm{ha}^{-1}$ ); 3) Soil + cattle manure (3:1); and 4) Soil + cattle manure (3:1) + NPK (N: $100 \mathrm{~kg} \mathrm{ha}^{-1}$; P: $100 \mathrm{~kg} \mathrm{ha}^{-1}$; and $\mathrm{K}: 50 \mathrm{~kg} \mathrm{ha}^{-1}$ ), and five light conditions: (1) ChromatiNet巴 red shade net; 2) Blue shade net (Polysack Plastic Industries); 3) Thermo-reflective Aluminet® shade net; 4) Black shade net; and 5) Full sun. Seedlings were collected after 60 days, and plant growth was analyzed. Seedlings grown under the thermo-reflective mesh with the substrate soil + cattle manure had the highest leaf dry mass. The best conditions to produce passion fruit seedlings are: soil + cattle manure and soil + cattle manure + NPK, using thermo-reflective and red shade nets and the full sun environment.
\end{abstract}

Additional keywords: initial plant growth; mineral nutrition; shade nets.

\section{Resumo}

O substrato desempenha grande importância no processo de produção de mudas, já que fornece as condições para o bom desenvolvimento das plantas, sendo necessária atenção quanto a sua escolha, pois o mesmo pode fornecer as melhores condições para a germinação das sementes e o desenvolvimento das mudas. $O$ objetivo deste trabalho foi avaliar o tipo de ambiente de luz e substrato que favorecem a produção de mudas de maracujazeiro de boa qualidade. O experimento foi conduzido no campo experimental da Universidade Federal do Recôncavo da Bahia, no município de Cruz das Almas-BA. O delineamento foi o inteiramente casualizado, em esquema fatorial $4 \times 5$, sendo quatro substratos: (1) Solo; 2) Solo + NPK (N: $100 \mathrm{~kg} \mathrm{ha}^{-1}, \mathrm{P}: 100 \mathrm{~kg} \mathrm{ha}^{-1} \mathrm{e}$ $\mathrm{K}: 50 \mathrm{~kg} \mathrm{ha}^{-1}$ ); 3) Solo + esterco bovino (3:1); e 4) Solo + esterco bovino (3:1) + NPK (N: $100 \mathrm{~kg} \mathrm{ha}^{-1}, \mathrm{P}: 100 \mathrm{~kg} \mathrm{ha}^{-1} \mathrm{e}$ $\mathrm{K}: 50 \mathrm{~kg} \mathrm{ha}^{-1}$ ), e cinco condições de luminosidade: (1) Malha ChromatiNet vermelha; 2) Malha azul (Polysack Plastic Industries); 3) Malha termorrefletora Aluminet; 4) Malha preta; e 5) Pleno sol. Após 60 dias, as mudas foram coletadas, e realizou-se as análises de crescimento das plantas. O maior valor de massa da matéria seca da parte aérea foi encontrado nas mudas cultivadas sob malha termorrefletora com o substrato solo + esterco bovino. As melhores condições para produzir mudas de maracujazeiro são: solo + esterco bovino e solo + esterco bovino + + NPK, usando as malhas termorrefletora, vermelha e ambiente a pleno sol.

Palavras-chave adicionais: crescimento inicial vegetal; malhas; nutrição mineral.

\section{Introduction}

Brazil is the world's largest producer of passion fruit (Passiflora edulis Sims. f. flavicarpa Deg). According to IBGE (2018), the production of this fruit in the country is 602,651 tons. It is a crop that has great economic importance, being produced in all regions Brazil. Moreover, it has good acceptance by consumers, with a large volume of production destined for the juice industry.

Brazilian fruit growing is expanding, favoring small and large producers that use high levels of technology (Bezerra, 2016). Seedling production is the result of several factors, including light, substrate, and temperature (Marçal et al., 2014). Producing healthy and vigorous seedlings is one of the determining factors for successful cultivation, as they allow the formation of high-yield plants (Almeida et al., 2014). 
The substrate has great importance in seedling production, as it provides the ideal conditions for plant development (Mesquita et al., 2012). Its choice must be carefully considered, since it can provide the best conditions both for the quality and intensity of seed germination and for root development (Negreiros et al., 2005). A substrate considered ideal must have good water retention capacity, low density, and contain all essential nutrients, with levels under the standard limits so as not to cause phytotoxicity (Dias et al., 2008).

Another important factor in seedling production is light. Studies show that the quality of light largely affects plant growth (Melo \& Alvarenga, 2009). In this sense, Chagas et al. (2013) report that the use of photoconverter nets is becoming common in protected crops. These nets alter the quantity and quality of solar irradiation with optical variations in the diffusion and reflectance of luminosity.

There are different types of photoconverter nets. The red photoconverter net has a high transmittance in the spectral range of red and far-red light, reducing yellow, green, and blue waves, and transmitting wavelengths greater than $590 \mathrm{~nm}$. In the blue net, light transmittance occurs in broadband at $470 \mathrm{~nm}$, with a peak greater than $750 \mathrm{~nm}$ in the far-red and infrared region (Souza et al., 2011). The black net is considered neutral, it only helps in reducing solar incidence, without influencing the quality of light (Pinto et al., 2014).

Another type of net used in protected crops is the thermo-reflective net. This net provides an aluminized shade, which decreases solar incidence in the summer, reducing the temperature, and guarantees heat storage in the winter, in addition to transmitting diffuse light, representing a gain in photosynthetic activity (Costa et al., 2012).

When evaluating the initial growth of papaya cultivated on different substrates under thermo-reflective nets, Moreira et al. (2017) found that seedlings cultivated in the substrate soil + commercial compound (SCC) performed better for root dry mass when subjected to thermo-reflective net. When grown in different light environments, passion fruit seedlings also showed higher chlorophyll a content and plant height when subjected to thermo-reflective net (Costa et al., 2018).

This study evaluates the effect of different substrates and light conditions on the production of yellow passion fruit seedlings.

\section{Material and methods}

The study was conducted in the experimental field of the Federal University of Recôncavo da Bahia (UFRB), in Cruz das Almas city, Bahia State, Brazil. Geographical coordinates are $12^{\circ} 40^{\prime} 19^{\prime \prime} \mathrm{S}$ and $39^{\circ} 06^{\prime} 22$ " W, and altitude of $225 \mathrm{~m}$. According to the Köppen classification, the climate is tropical (Af), hot and humid. Average annual rainfall is $1,224 \mathrm{~mm}$, average annual temperature is $24.5^{\circ} \mathrm{C}$, and relative air humidity is approximately $82 \%$. Four structures of different colors were built, which were $4 \mathrm{~m}$ wide, $8 \mathrm{~m}$ long, and $2 \mathrm{~m}$ high, as shown in figure 1.
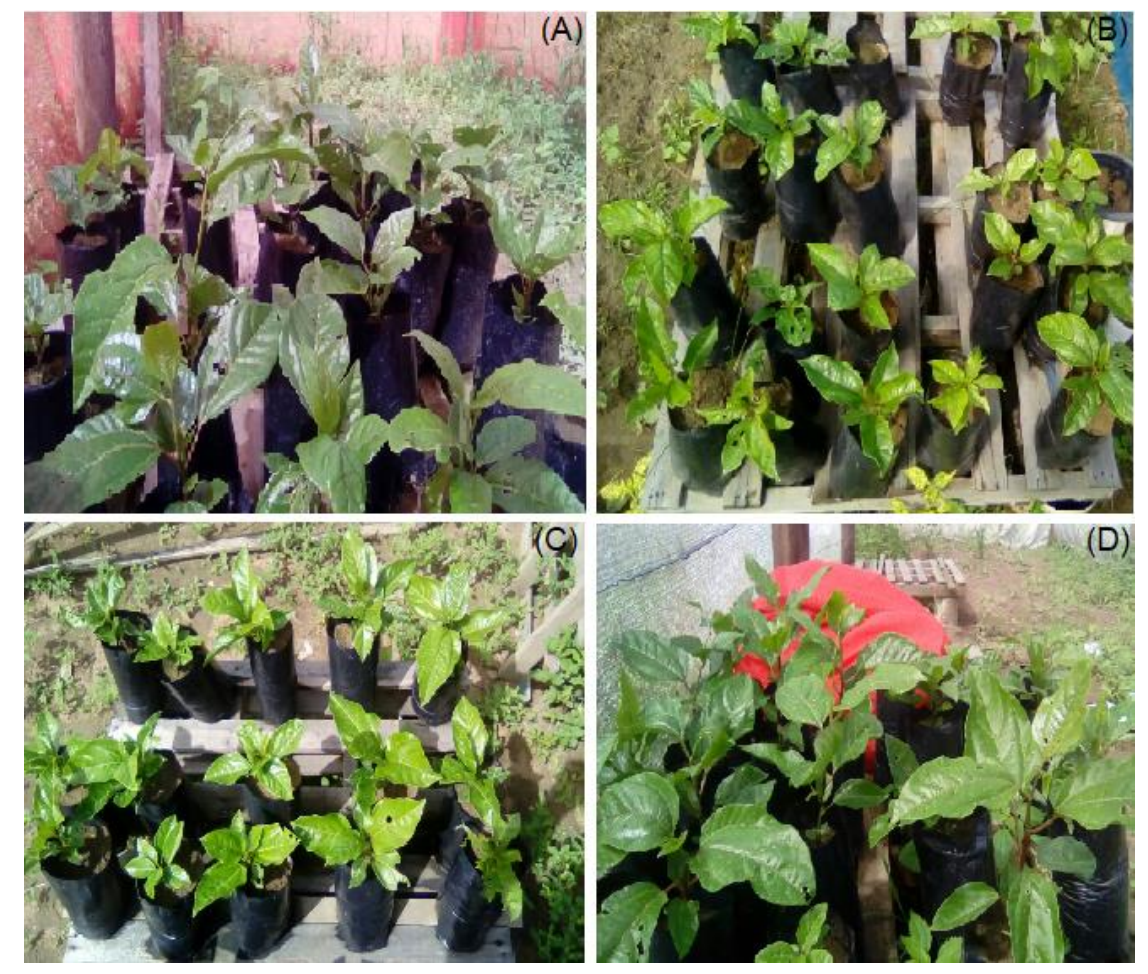

Figure 1 - Structure for the production of passion fruit seedlings in red shade net $(A)$, blue shade net $(B)$, full sun (C) and thermo-reflective Aluminet ${ }^{\circledR}$ shade net (D). 
The experimental design was completely randomized, with 20 plants per net, in a $5 \times 4$ factorial scheme with subdivided plots. The main factor was the light conditions obtained with the use of nets: 1) ChromatiNet $\AA$ red shade net; 2 ) Blue net (Polysack Plastic Industries); 3) Thermo-reflective Aluminet ${ }^{\circledR}$ shade net; 4) Black net; and 5) Full sun, with five replicates, arranged in plots subdivided in space, totaling 100 experimental units. The secondary treatment considered four substrates: 1) Soil; 2) Soil + NPK (N: :100 kg ha-1; P: $100 \mathrm{~kg} \mathrm{ha}^{-1}$; and K: $\left.50 \mathrm{~kg} \mathrm{ha}^{-1}\right)$; 3) Soil + + cattle manure (3:1); and 4) Soil + cattle manure (3:1) +
+ NPK (N: $100 \mathrm{~kg} \mathrm{ha}^{-1}$; P: $100 \mathrm{~kg} \mathrm{ha}^{-1}$; and K: $50 \mathrm{~kg} \mathrm{ha}^{-1}$ ). The different light environments were allocated in the plots, and the different substrates in the subplots. The soil used was a Dystrophic Yellow Latosol collected from the superficial layer $(0.00-0.20 \mathrm{~m})$ on the experimental campus of UFRB. Sowing was performed in black polyethylene bags $0.22 \mathrm{~m}$ high and $0.18 \mathrm{~m}$ in diameter, using two seeds per bag.

Soil and cattle manure were sieved in a $4 \mathrm{~mm}$ mesh sieve. Soil chemical analysis was performed by the AKLO Laboratory for Soil, Water, and Plant Analysis (Table 1).

Table 1 - Results of the soil chemical analysis.

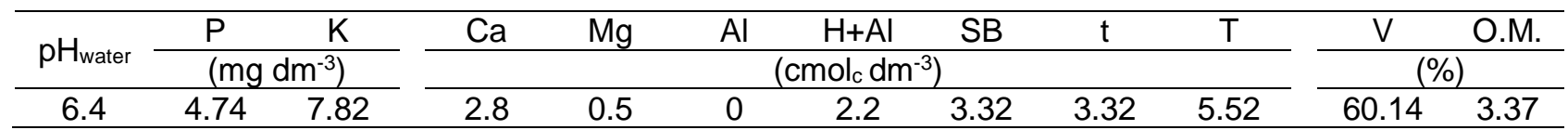

SB - sum of bases; $t$ - cations exchange capacity; $\mathrm{T}$ - cations exchange capacity at $\mathrm{pH}$ 7.0; $\mathrm{V}$ - base saturation; O.M. - organic matter.

The following variables were analyzed at 60 days for all seedlings: stem diameter (SD), at $1 \mathrm{~cm}$ from the substrate level, with the aid of a pachymeter with an accuracy of $0.01 \mathrm{~mm}$; number of leaves (NL), counted manually, considering leaves at least $2 / 3$ the size of an already established leaf; root length $(R L)$, measuring from the upper base to the highest root concentration with the aid of a tape measure. Chlorophyll index $(\mathrm{FCl}$ - Falker Chlorophyll Index) data were collected between 8 a.m. and 10 a.m. using an electronic meter (Falker, model CFL1030), with readings taken on three leaves from the middle third of each plant.

Leaves, stem, and roots were individually packed in paper bags and placed in an oven with forced air circulation at $40 \pm 2 \stackrel{\circ}{\circ}$ until constant mass. Later, the following were determined using an analytical balance with an accuracy of $10^{-3} \mathrm{~g}$ : leaf dry mass (LDM), stem dry mass (SDM), root dry mass (RDM), and total dry mass (TDM). Dickson Quality Index (DQI) was obtained according to Dickson et al. (1960).

Plant growth data were submitted to analysis of variance using $\mathrm{R}$ software (R Development Core Team, 2017). Depending on the level of significance, the Tukey test was applied at $5 \%$ probability to compare means.

\section{Results and discussion}

Analysis of variance revealed a significant interaction between environments and substrates for shoot dry mass in the production of passion fruit seedlings (Table 2).

Table 2 - Shoot dry mass of passion fruit seedlings as function of environment and substrate interaction.

\begin{tabular}{lllclc}
\hline \multirow{2}{*}{ Substrate $^{1}$} & \multicolumn{5}{c}{ Shoot dry mass $(\mathrm{g})$} \\
\cline { 2 - 6 } & Full sun & Red net & Thermo-reflective net & Black net & Blue net \\
\hline 1 & $1.25 \mathrm{aC}^{2}$ & $2.20 \mathrm{aA}$ & $1.99 \mathrm{aC}$ & $1.69 \mathrm{aA}$ & $1.72 \mathrm{aA}$ \\
2 & $1.96 \mathrm{bBC}$ & $2.16 \mathrm{abA}$ & $3.92 \mathrm{aAB}$ & $2.24 \mathrm{abA}$ & $1.95 \mathrm{bA}$ \\
3 & $3.0 \mathrm{abcAB}$ & $3.30 \mathrm{abA}$ & $4.40 \mathrm{aA}$ & $1.61 \mathrm{bcA}$ & $1.39 \mathrm{cA}$ \\
4 & $3.68 \mathrm{aA}$ & $2.22 \mathrm{aA}$ & $2.69 \mathrm{aBC}$ & $2.21 \mathrm{aA}$ & $2.63 \mathrm{aA}$ \\
\hline
\end{tabular}

${ }^{1}$ Substrate: 1) Soil; 2) Soil + NPK (N: $100 \mathrm{~kg} \mathrm{ha}^{-1}, \mathrm{P}: 100 \mathrm{~kg} \mathrm{ha}^{-1}$ and K: $50 \mathrm{~kg} \mathrm{ha}^{-1}$ ); 3) Soil + cattle manure (3:1); and 4) Soil + + cattle manure (3:1) + NPK (N: $100 \mathrm{~kg} \mathrm{ha}^{-1}, \mathrm{P}: 100 \mathrm{~kg} \mathrm{ha}^{-1}$ and $\left.\mathrm{K}: 50 \mathrm{~kg} \mathrm{ha}^{-1}\right){ }^{2}$ Means followed by the uppercase and lowercase letters in the column and line, respectively, do not differ by Tukey test $(p>0.05)$.

By unfolding the interaction, fixing the type of substrate, and varying the environments, shoot dry mass increased with the use of red, black, and blue nets for any substrate, not differing statistically from each other. According to Henrique et al. (2011), colored nets aim to change the radiation spectrum available to the plant, allowing metabolic adjustments in the photosynthetic system. The authors also emphasize that the use of red and blue light improves plant development.
Leite et al. (2004) state that some plants remain with their stomata open under the blue net even in nonideal conditions, thus affecting seedling development in adverse situations such as periods of drought and high temperatures. However, these results cannot be generalized, since the influence of radiation quality on plant growth and development is species-related (Braga et al., 2009).

Similar results of total dry mass were achieved by Melo \& Alvarenga (2009) in the cultivation of 
Catharanthus roseus under red net. The distribution of dry matter among different organs is characteristic of plant species, and demonstrates the adaptation to different environmental conditions.

By fixing the environments and varying the substrates, passion fruit seedlings performed better for shoot dry mass when the substrate was composed only of soil and soil + cattle manure + NPK, not differing for all environments. Seedlings produced with substrate composed of soil + NPK performed better under red, thermo-reflective, and black nets. Seedlings produced with the substrate soil + cattle manure developed less under black and blue nets, while the other nets did not differ statistically. Studying the production of papaya seedlings, Brito et al. (2014) demonstrated that the cattle manure rate influences plant height, but the slow mineralization, and consequent availability of nutrients, may impair plant performance, as occurred with the seedlings subjected to red and thermo-reflective nets and to the full sun environment.

Analysis of variance revealed that passion fruit seedlings grown in different light environments were significantly influenced at $5 \%$ probability (Table 3 ).

Table 3 - Average values for the variables stem diameter (SD), number of leaves (NL) and total dry mass (TDM) of passion fruit seedlings grown in different light environments.

\begin{tabular}{lcrccc}
\hline Variables & Full sun & Red net & Blue net & Thermo-reflective & Black net \\
\hline SD $(\mathrm{mm})$ & $3.63 \mathrm{ab}^{1}$ & $3.42 \mathrm{ab}$ & $3.32 \mathrm{ab}$ & $3.66 \mathrm{a}$ & $2.96 \mathrm{~b}$ \\
$\mathrm{NL}$ & $16.50 \mathrm{a}$ & $14.05 \mathrm{ab}$ & $13.00 \mathrm{~b}$ & $13.10 \mathrm{~b}$ & $13.60 \mathrm{~b}$ \\
TDM $(\mathrm{g})$ & $5.06 \mathrm{ab}$ & $4.56 \mathrm{ab}$ & $3.64 \mathrm{~b}$ & $6.06 \mathrm{a}$ & $3.90 \mathrm{~b}$ \\
\hline
\end{tabular}

${ }^{1}$ Means followed by the same letters in the line do not differ by Tukey $(p>0.05)$.

Passion fruit seedlings performed worse for stem diameter when grown under the black net, while the other environments did not differ statistically from each other. Seedlings grown in full sun and under the red net showed a higher number of leaves; the other environments also did not differ for this variable. According to Thompson et al. (1992), under intense shading, there is a tendency for shade-intolerant species to reduce their growth, mainly when presenting a low reserve of seed carbohydrates.

For total dry mass, seedlings grown in full sun and under red and thermo-reflective nets performed better than the others. Using a thermo-reflective net, Medina \& Machado (2006) observed an increase in photosynthesis that caused a $26 \%$ to $40 \%$ precocity in the formation of citrus seedlings. Leite et al. (2004) describe that, because thermo-reflective nets are made of aluminum, they reflect heat waves, decreasing temperature by 10 to $20 \%$.

These results differ from those found by Chagas et al. (2013), who demonstrated a higher total dry matter yield in Japanese mint plants when using thermo-reflective compared to red net. Exposure to farred and red light during growth and leaf development influences chloroplast development to more efficiently ensure plant survival (Kasperbauer \& Hamilton, 1984). This may have increased the photosynthetic capacity of uncovered plants and plants grown under red net when compared to those grown under blue and thermoreflective nets. As a result, the transfer of light in the farred and red wavelength range is greater, providing better quality of light and diffused light and, consequently, high vegetative development, rooting, and production ( $\mathrm{Li}, 2006)$.

Corrêa (2008) studied the effect of black, red, and blue nets on plant growth, essential oil content, and plant anatomy of Origanum vulgare. The author concluded that the nets did not influence total dry biomass and leaf area, but the full sun environment significantly reduced these variables. In addition, Oliveira et al. (2008) emphasize that the results show that the influence of light quality is related to the species and region of the plant studied. Thus, it is necessary to better study the effect of these nets on other fruit trees, as well as on vegetable and medicinal species.

The data showed no significant interaction between light environments and substrate types for root length (RL), stem diameter (SD), number of leaves (NL), root dry mass (RDW), total dry mass (TDM), chlorophyll a (Chl a), total chlorophyll (Chl t), and Dickson Quality Index (DQI) (Table 4).

Root length, stem diameter, number of leaves, root dry mass, total dry mass, chlorophyll a, total chlorophyll, and Dickson Quality Index had lower values when seedlings were grown only in soil (1); the other substrates did not differ statistically from each other, except for root dry mass in the substrate soil + cattle manure (3:1) (3).

Dickson Quality Index serves as an indicator of seedling quality because its calculation considers a balanced formula that contains relationships between morphological parameters (Saraiva et al., 2014). Studying the initial development of yellow passion fruit, Dantas et al. (2012) found that the increase in the proportion of cattle manure in the substrate promoted the highest estimated value of 0.2 for Dickson Quality Index with the use of the estimated rate of $41.4 \%$ cattle manure in the substrate composition. This value promoted an increase of $109.0 \%$ for this index when compared to the control.

Studying the production of yellow passion fruit seedlings in trays, Almeida et al. (2011) observed that the substrates $50 \%$ soil $+50 \%$ cattle manure and $50 \%$ soil $+50 \%$ goat manure promoted the highest values of Dickson Quality Index: 1.2 and 1.5, respectively, not differing from each other, but differing statistically from the other substrates used.

Therefore, the substrate influenced shoot growth, directly affecting the root system, as also mentioned by Hartmann et al. (1990). 
Table 4 - Average values of root length (RL), stem diameter (SD), number of leaves (NL), root dry (RDM), total dry mass (TDM), chlorophyll a ( $\mathrm{Chl}$ a), total chlorophyll ( $\mathrm{Chl}$ t) and Dickson Quality Index (DQI) das mudas de maracujazeiro cultivadas em diferentes substratos (Cruz das Almas-BA, 2018).

\begin{tabular}{lrrrc}
\hline Characteristics & \multicolumn{4}{c}{ Substrate $^{1}$} \\
\hline $\mathrm{RL}(\mathrm{cm})$ & 1 & 2 & 3 & 4 \\
$\mathrm{SD}(\mathrm{mm})$ & $27.26 \mathrm{~b}^{3}$ & $28.16 \mathrm{ab}$ & $29.92 \mathrm{ab}$ & $30.26 \mathrm{a}$ \\
$\mathrm{NL}$ & $3.03 \mathrm{~b}$ & $3.44 \mathrm{ab}$ & $3.62 \mathrm{a}$ & $3.50 \mathrm{ab}$ \\
$\mathrm{RDM}(\mathrm{g})$ & $12.08 \mathrm{~b}$ & $14.24 \mathrm{ab}$ & $14.8 \mathrm{a}$ & $15.08 \mathrm{a}$ \\
$\mathrm{TDM}(\mathrm{g})$ & $1.64 \mathrm{~b}$ & $2.19 \mathrm{ab}$ & $2.07 \mathrm{~b}$ & $3.01 \mathrm{a}$ \\
$\mathrm{Chl} \mathrm{a} \mathrm{(FCl})^{2}$ & $3.41 \mathrm{~b}$ & $4.65 \mathrm{ab}$ & $4.81 \mathrm{a}$ & $5.70 \mathrm{a}$ \\
Chl t (FCl) & $35.42 \mathrm{~b}$ & $37.18 \mathrm{ab}$ & $38.62 \mathrm{a}$ & $37.30 \mathrm{ab}$ \\
DQI & $49.39 \mathrm{~b}$ & $52.23 \mathrm{ab}$ & $54.61 \mathrm{a}$ & $51.83 \mathrm{ab}$ \\
\hline
\end{tabular}

${ }^{1}$ Substrate: 1) Soil; 2) Soil + NPK (N: $100 \mathrm{~kg} \mathrm{ha}^{-1}, \mathrm{P}: 100 \mathrm{~kg} \mathrm{ha}^{-1}$ and K: $\left.50 \mathrm{~kg} \mathrm{ha}^{-1}\right)$; 3) Soil + cattle manure (3:1); and 4) Soil + cattle manure (3:1) + NPK (N: $100 \mathrm{~kg} \mathrm{ha}^{-1}, \mathrm{P}: 100 \mathrm{~kg} \mathrm{ha}^{-1}$ and K: $\left.50 \mathrm{~kg} \mathrm{ha}^{-1}\right) .{ }^{2}$ Falker chlorophyll index. ${ }^{3}$ Means followed by the same letters in the line do not differ by Tukey $(p>0.05)$.

\section{Conclusions}

It is recommended to use the substrates soil + + cattle manure (3:1) or soil + cattle manure (3:1) + NPK (N: 100 kg ha-1; P: $100 \mathrm{~kg} \mathrm{ha}^{-1}$; and $\mathrm{K}: 50 \mathrm{~kg} \mathrm{ha}^{-1}$ ), in addition to red and thermo-reflective nets or the full sun environment for the production of yellow passion fruit seedlings.

\section{References}

Almeida JPN, Barros GL, Silva GBT, Procópio LJS, Mendonça V (2011) Substratos alternativos na produção de mudas de maracujazeiro amarelo em bandeja. Revista Verde 6(1):188-195.

Almeida JPN, Lessa BTF, Paiva EP, Arrais LG, Tosta MS, Mendonça V (2014) Inoculação de fungo micorrízico e utilização de substratos comerciais para produção de plântulas de mamoeiro (Carica papaya L.). Revista de Ciências Agrárias 37(3):280-285.

Bezerra JH (2016) A fruticultura familiar e a extensão rural: um estudo de caso no município de Iguatu-CE. Faculdades Est (Dissertação de mestrado em Teologia).

Braga FT, Pasqual M, Castro EM, Dignart SL, Briagiotti G, Porto JMP (2009) Qualidade de luz no cultivo in vitro de Dendranthema grandiflorum cv. Rage: características morfofisiológicas. Ciência e Agrotecnologia 33(2):502-508.

Brito CFB, Fonseca VA, Bebé FV, Santos LG (2014) Desenvolvimento inicial do milho submetido a doses de esterco bovino. Revista Verde 9(3):244-250.

Chagas JH, Pinto JEBP, Bertolucci SKV, Costa AG, Jesus HCR, Alves PB (2013) Produção, teor e composição química do óleo de hortelã-japonesa cultivadas sob malhas fotoconversoras. Horticultura brasileira 31(2):297-303.
Corrêa RM (2008) Adubação orgânica, intensidade e qualidade de luz no crescimento de plantas, características anatômicas e composição química do óleo essencial de orégano (Origanum vulgare L.). Universidade Federal de Lavras (Tese de doutorado em Agronomia).

Costa AG, Chagas JH, Pinto JEBP, Bertolucci SKV (2012) Crescimento vegetativo e produção de óleo essencial de hortelã-pimenta cultivada sob malhas. Pesquisa Agropecuária Brasileira 47(4):534-540.

Costa FM, Anjos GL, Camilo GBM, Oliveira UC, Souza GS, Santos AR (2018) Produção de mudas de maracujazeiro amarelo em diferentes composições de substrato e ambiente. Revista de Ciências Agrárias 41(1):138-146.

Dantas LLGR, Leite GA, Tosta MS, Góes GB, Tosta PAF, Maracajá PB (2012) Esterco bovino no desenvolvimento inicial de maracujazeiro-amarelo. Revista Verde 7(4):101-107.

Dias MA, Lopes JC, Corrêa NB, Dias NCFS (2008) Germinação de sementes e desenvolvimento de plantas de pimenta malagueta em função do substrato e da lâmina de água. Revista Brasileira de Sementes 30(3):115-121.

Dickson A, Leaf AL, Hosner JF (1960) Quality appraisal of white spruce and white pine seedling stock in nurseries. Forestry Chronicle 36:10-13.

Henrique PC, Alves JD, Deuner S, Goulart PFP, Livramento DE (2011) Aspectos fisiológicos do desenvolvimento de mudas de café cultivadas sob telas de diferentes colorações. Pesquisa Agropecuária Brasileira 46(5):458-465.

IBGE - Instituto Brasileiro de Geografia e Estatística (2018) Produção agrícola municipal. Disponível em: <https://sidra.ibge.gov.br/pesquisa/pam/tabelas>

(Acesso em 01 jan 2019). 
Kasperbauer MJ, Hamilton JL (1984) Chloroplast structure and starch grain accumulation in leaves that received different red and far-red levels during development. Plant Physiology 74(4):967-970.

Hartmann HT, Kester DE, Davies JFT (1990) Plant propagation: principles and practices. Prentice Hall. $647 p$.

Leite CA, Ito RM, Gerald LTC, Fagnani MA (2004) Manejo do espectro de luz através de malhas coloridas visando o controle do crescimento e florescimento de Phalaenopsis sp. In: Jornada científica e fipado cefet, I. Bambuí: Livro de resumos, 1-4p.

Li JC (2006) Uso de mallas en invernaderos. Horticultura Internacional, n. n. extra:86-91.

Marçal TS, Martins MQ, Coelho RL, Amaral JAT, Ferreira A (2014) Emergência e crescimento inicial de plântulas de tangerineira 'Cleópatra' submetidas a diferentes níveis de sombreamento. Nucleus 11(1):6572.

Medina C, Machado EC (2006) Uma nova luz para o futuro dos pomares. IAC. $4 p$.

Melo AAME, Alvarenga AA (2009) Sombreamento de plantas de Catharanthus roseus (L.) G. Don 'Pacifica White' por malhas coloridas: desenvolvendo vegetativo. Ciências e Climatologia 33(2):514-520.

Mesquita EF, Chaves LHG, Freitas BV, Silva GA, Souza MVR, Andrade R (2012) Produção de mudas de mamoeiro em função de substratos contendo esterco bovino e volume de recipientes. Revista Brasileira de Ciências Agrárias 7(1):58-65.

Moreira GM, Souza GS, Santos AR (2017) Crescimento inicial de mamoeiro cultivado em diferentes substratos e sob telas termorefletoras. Journal of Agronomic Sciences 6(1):201-218.
Negreiros J, Braga L, Alvares V, Bruckner C (2005) Diferentes substratos na formação de mudas de mamoeiro do Grupo Solo. Revista Brasileira Agrociência 11(1):101-103.

Oliveira JR, Paulo MW, Corrêa RM, Reis ES, Carvalho MA, Rodrigues LE, Reis MM (2008) Cultivos agrícolas utilizando telas coloridas e termorefletoras. In: jornada científica, 1., 2008, Bambuí. Bambuí: CEFET 2008. 1$-5 p$.

Pinto JEBP, Ferraz EO, Bertolucci SKV, Silveira HRO, Santos AS, Silva GM (2014) Produção de biomassa e óleo essencial em mil folhas cultivada sob telas coloridas. Horticultura Brasileira 32(3):321-326.

R Development Core Team (2017) R: a language and environment for statistical computing. R Foundation for Statistical Computing, Disponível em: <https://www.Rproject.org/ $\geq$ (Acesso em 01 fev 2018).

Thompson WA, Huang LK, Kriedemann PE (1992) Photosynthetic response to light and nutrients in suntolerant rainforest trees. II. Leaf gas exchange and component processes of photosynthesis. Australian Journal of Plant Physiology 19(1):19-42.

Saraiva GFR, Souza GM, Rodrigues JD (2014) Aclimatação e fisiologia de mudas de guarandi cultivadas em telas de sombreamento foto-protetoras. Colloquium Agrarie 10(2):1-10.

Souza GS, Castro EM, Soares AM, Santos AR, Elves E (2011) Teores de pigmento fotossintético, taxa de fotossíntese e estruturas de cloroplasto de plantas de Mikania laevigata Schultz Bip. Ex. Baker cultivadas sob malhas coloridas. Semina: Ciências Agrárias 32(4):1843-1854. 